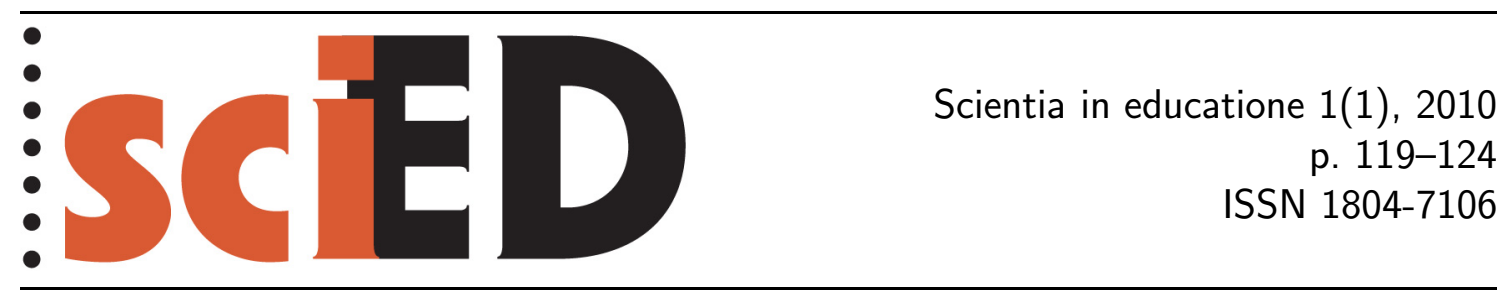

\title{
Doktorské studium v oblasti didaktiky chemie - vývoj a současnost
}

\author{
Hana Čtrnáctová, Marta Klečková
}

\begin{abstract}
Abstrakt
Př́spěvek je věnován vývoji oboru zaměřeného na chemické vzdělávání z hlediska jeho institucionalizace $\mathrm{v}$ rámci vědecké přípravy a doktorského studia. Charakterizuje tyto formy studia, jejich význam a dosažené výsledky. První část příspěvku je věnována vědecké přípravě v oboru Teorie vyučování chemii, která zde existovala od 70. let 20. století. Ve druhé části př́spěvku se zaměříme na význam doktorského studia pro rozvoj oboru chemické vzdělávání a na charakteristiku kvantitativních a kvalitativních ukazatelů doktorských studijních programů Vzdělávání v chemii a Didaktika chemie v České republice. Toto studium bylo akreditováno v r. 2003 na Př́rodovědecké fakultě UK v Praze a v r. 2007 na Př́rodovědecké fakultě UP v Olomouci. V př́spěvku uvádíme hlavní parametry a požadavky tohoto studia, zaměření doktorských prací od r. 2004 do současnosti a jejich př́nos pro další vývoj oboru.
\end{abstract}

Klíčová slova: vědecká př́iprava, doktorské studium, vzdělávání v chemii, studijní plány a témata prací.

\section{Doctoral Studies in the Area of Didactics of Chemistry in the Czech Republic - Development and the Current State}

\begin{abstract}
The contribution concerns the development of the subject of chemistry education with respect to its institutionalization during scientific preparation and doctoral studies. It characterizes these forms of studies, their importance and the results obtained. The first part of the contribution concerns the scientific preparation in the subject: The theory of chemistry teaching which has existed here since 1970's. In the second part of the contribution, we'll deal with the meaning of doctoral studies for the development of the subject of chemistry education and the characteristics of quantitative and qualitative measures of the doctoral studies programme: Education in Chemistry and Didactics of Chemistry in the Czech Republic. These studies were accredited at the Charles University - Faculty of Science in 2003, and at Palacky University - Faculty of Science in 2007. In the contribution, we show the main parameters and demands of this study, the aim of doctoral dissertations since 2004, and their contributions for the further development of the subject.
\end{abstract}

Key words: scientific preparation, doctoral studies, chemistry education, study plans and dissertation themes. 


\section{1 ÚVOD}

Každý vědecký obor usiluje o svůj dalšś rozvoj a uznání i formou akreditace oboru na úrovni všech stupňů vysokoškolského studia. Význam pro jeho další vývoj má především nejvyšší stupeň tohoto studia, realizovaný dříve jako tzv. vědecká příprava, nyní jako doktorské studium. Právě studenti tohoto studia jsou těmi, kteří pod vedením svých školitelů výrazně přispívají k řešení aktuálních otázek oboru a posunování jeho vývoje kupředu (Brockmeyenová-Fenclová aj., 2000; McMillan-Wergin, 1998).

V období do r. 1989 se uvedená forma studia realizovala v tzv. vědecké př́ípravě. V oblasti didaktiky chemie byla tato příprava zavedena již od začátku 70 . let 20. století a významnou měrou se podílela na rozvoji oboru.

$\mathrm{V}$ 90. letech 20. století byla většina oborů vědecké přípravy transformována v obory doktorského studia. Význam tohoto studia se ještě zvýšil v době, kdy v souladu se závěry Boloňské deklarace došlo k restrukturalizaci studia na vysokých školách a $\mathrm{k}$ přechodu na studium tř́stupňové: bakalářské, magisterské a doktorské. Tato restruktualizace se týkala i oborů učitelských a vytížila studenty učitelství a jejich pedagogy takovým způsobem, že doktorské studium se stalo pro další vývoj oboru zcela nezbytné. Problém však tkvěl v tom, že vědecká příprava v oborových didaktikách vesměs z různých důvodů dosud v doktorské studium transformována nebyla, a proto byl náš zájem o akreditaci tohoto studia velmi výrazný. Po značném úsilí řady zainteresovaných pracovníků tato snaha v oboru zaměřeném na chemické vzdělávání skončila úspěchem. V r. 2003 byla udělena akreditace doktorskému programu Vzdělávání v chemii na PřF UK v Praze a v r. 2007 v rámci doktorského programu Chemie došlo k akreditaci oboru Didaktika chemie na PřF UP v Olomouci. Proto lze rekapitulovat dosud dosažené výsledky.

\section{TEORIE VYUČOVÁNí CHEMII - OBOR VĚDECKÉ PŘÍPRAVY V OBDOBÍ LET 1972-1994}

$\mathrm{V}$ průběhu 60 . let 20 . století došlo $\mathrm{k}$ výraznému rozvoji a také institucionalizaci oborů, které se věnují problematice vzdělávání v jednotlivých oblastech lidské činnosti. Jedním z nich bylo také vzdělávání v chemii. Původní označení oboru „Metodika vyučování chemii“ se změnilo na název „Teorie vyučování chemii“, postupně se užívaly i názvy jiné, nejčastěji „Didaktika chemie“, ale také „Pedagogika chemie“ a další (Banýr, 2002; Bílek, 2003; Hellberg, Bílek, 2000).

Na počátku 70. let dochází k ustanovení možnosti absolvovat v tomto oboru tř́letou interní nebo pětiletou externí aspiranturu, tedy soustavnou přípravu absolventů vysoké školy pro vědeckou práci, která je ukončena obhajobou kandidátské disertační práce a získáním vědecké hodnosti kandidát věd (CSc.). V období 1972-1994 byla $\mathrm{v}$ bývalém Československu tato vědecká příprava v oboru s názvem „Teorie vyučování chemii“" realizována pouze na třech fakultách dvou univerzit. Na Univerzitě Karlově v Praze na fakultách přrírodovědecké a pedagogické, na Univerzitě Komenského v Bratislavě na fakultě přírodovědecké. V uvedeném období prošla vědeckou přípravou v tomto oboru řada absolventů učitelství chemie. Jen menší část z nich, přibližně $20 \%$ ze všech přijatých zájemců, však studium úspěšně ukončila (Čtrnáctová, 2006).

Celkem bylo $\mathrm{v}$ onom období obhájeno 45 prací, což představuje v průměru 2 práce ročně na všech uvedených fakultách dohromady. Zaměření prací bylo v průběhu téměř 20 let, kdy tato vědecká příprava probíhala, poměrně různorodé, jak ukazuje obr. 1. 


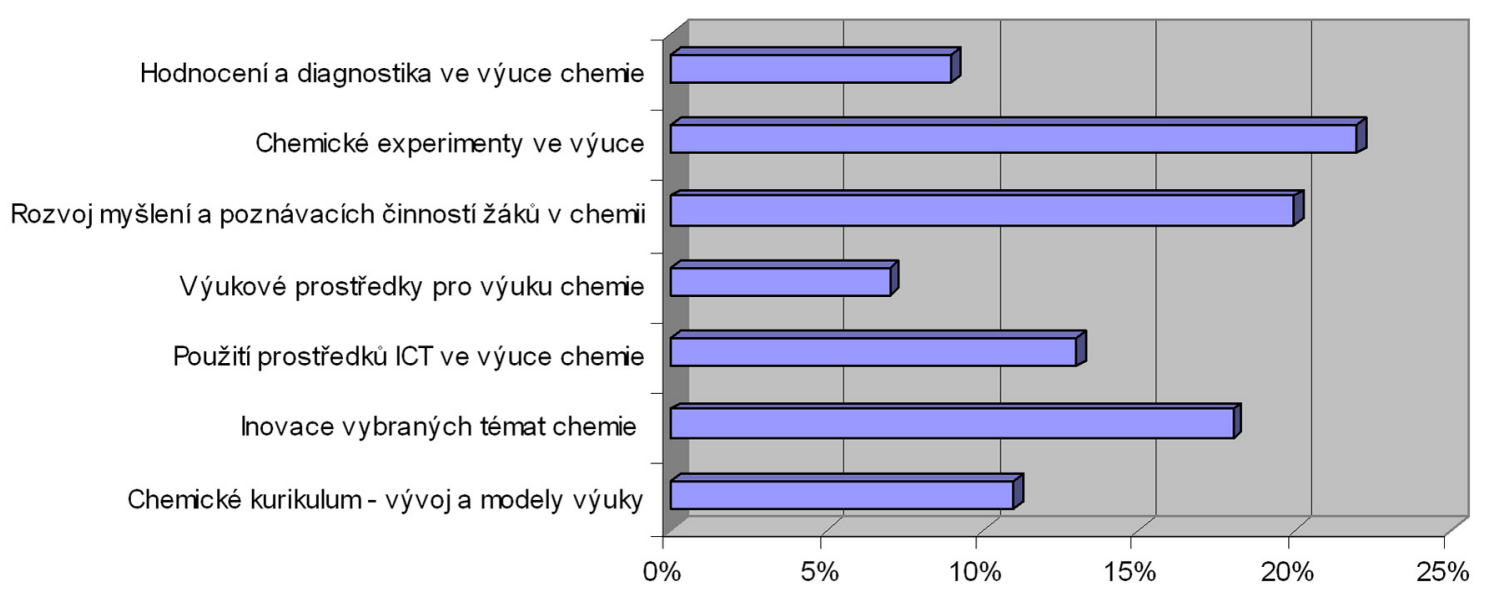

Obr. 1: Témata prací vědecké přípravy z didaktiky chemie (1972-1994)

Otázkám pojetí výuky chemie a chemického kurikula byla věnována pouze asi jedna desetina prací. Jedním z důvodů byla nepochybně nová koncepce výuky chemie, která byla v polovině 70. let 20. století stanovena MŠMT a právě v letech 1976-1988 postupně vcházela v platnost. Téměř $20 \%$ prací se zaměřovalo na inovaci určitých vybraných tematických celků učiva chemie na úrovni základních a středních škol. Didaktickým prostředkům, chemickým experimentům a využití ICT ve výuce chemie se v tomto období věnovalo přes $40 \%$ prací, což svědčí o významu, který byl těmto oblastem didaktiky chemie přikládán. Značná část prací byla zaměřena na zjištování souvislostí mezi rozvojem myšlení žáků a jejich poznávacích činností a výukou chemie (1/5 prací) a na oblast diagnostiky a hodnocení výuky (přibližně $1 / 10$ prací).

Vytvořené práce zásadně přispívaly $\mathrm{k}$ řešení aktuálních otázek oboru didaktika chemie v uvedeném období i k růstu personálního zabezpečení oboru. Proto lze toto období vývoje oboru didaktika chemie hodnotit přes všechny obtíže jednoznačně kladně. Přineslo řadu cenných výsledků, významně přispělo k rozvoji oboru a ukázalo možnosti jeho dalšího vývoje (Pfeifer aj., 2002; Schmidt aj, 1992).

\section{DoKTORSKÉ STUdiUM: VZDĚLÁVÁNí V CHEMII A DidAKTIKA CHEMie V OBDobí 2003-2010}

Vzhledem k zájmu o obor „Teorie vyučování chemii“ mezi pracovníky především vysokých škol a institucí MŠMT, a vzhledem k výsledkům, které byly v tomto oboru dosahovány, se předpokládalo, že nenastanou žádné komplikace a obor bude, tak jako obory jiné, na počátku 90. let akreditován jako obor doktorského studia. Nicméně realita byla z řady přičin zcela jiná. O akreditaci oboru „Vzdělávání v chemii“ bylo nutno usilovat více než 10 let - byla udělena PřF UK v Praze až na podzim r. 2003. V r. 2007 byla tato akreditace prodloužena a PřF UP v Olomouci byla udělena další akreditace pro obor „Didaktika chemie“. V současnosti jsme tak jedním z několika akreditovaných oborů oborových didaktik v ČR. Zájem o studium uvedeného oboru je mezi absolventy učitelského studia chemie značný, jak dokumentují tabulky 1 a 2 (Studium - Agenda DS, 2010; Studium - DS, 2010).

Z údajů v tabulkách je patrné, že počet studentů v uplynulých pěti letech poměrně rychle vzrůstal. V současnosti je registrováno celkem 63 studentů v prezenční nebo kombinované formě studia. Z původních 85 přijatých studentů jich 14 přerušilo nebo ukončilo studim na vlastní žádost, především z rodinných důvodů nebo 
Tab. 1: Počet studentů na Př́rodovědecké fakultě UK v Praze (2004-2010)

\begin{tabular}{|c|c|c|c|}
\hline Školní rok & Přijato & Studuje & Obhajoba \\
\hline $2004-2005$ & 16 & 16 & 0 \\
\hline $2005-2006$ & 8 & 24 & 0 \\
\hline $2006-2007$ & 15 & 36 & 1 \\
\hline $2007-2008$ & 9 & 44 & 3 \\
\hline $2008-2009$ & 12 & 50 & 1 \\
\hline $2009-2010$ & 7 & 54 & 1 \\
\hline $2010-2011$ & 8 & 58 & 2 \\
\hline
\end{tabular}

Tab. 2: Počet studentů na Přírodovědecké fakultě UP v Olomouci (2007-2010)

\begin{tabular}{|c|c|c|c|}
\hline Školní rok & Přijato & Studuje & Obhajoba \\
\hline $2007-2008$ & - & - & - \\
\hline $2008-2009$ & 5 & 3 & - \\
\hline $2009-2010$ & 4 & 5 & - \\
\hline $2010-2011$ & 1 & 5 & - \\
\hline
\end{tabular}

kvůli zaneprázdněnosti jinými úkoly, osm studentů již studium úspěšně absolvovalo (Čtrnáctová, 2006).

V rámci studia se vyžaduje absolvování 2-5 předmětů zakončených zkouškou, včetně zkoušky jazykové, a složení státní doktorské zkoušky. Součástí studia je také pedagogická a publikační činnost studenta a aktivní účast na nejrůznějších akcích a aktivitách z oblasti chemického vzdělávání, např. účast na mezinárodních konferencích a seminářích, stáže na domácích i zahraničních odborných pracovištích aj. Všechny tyto složky jsou součástí individuálního studijního plánu každého studenta, který si se svým školitelem na začátku studia sestaví a po schválení oborovou radou postupně plní.

Finální částí studia je vypracování a obhájení dizertační práce. Zvolená témata doktorských prací a jejich zastoupení ukazuje obr. 2.

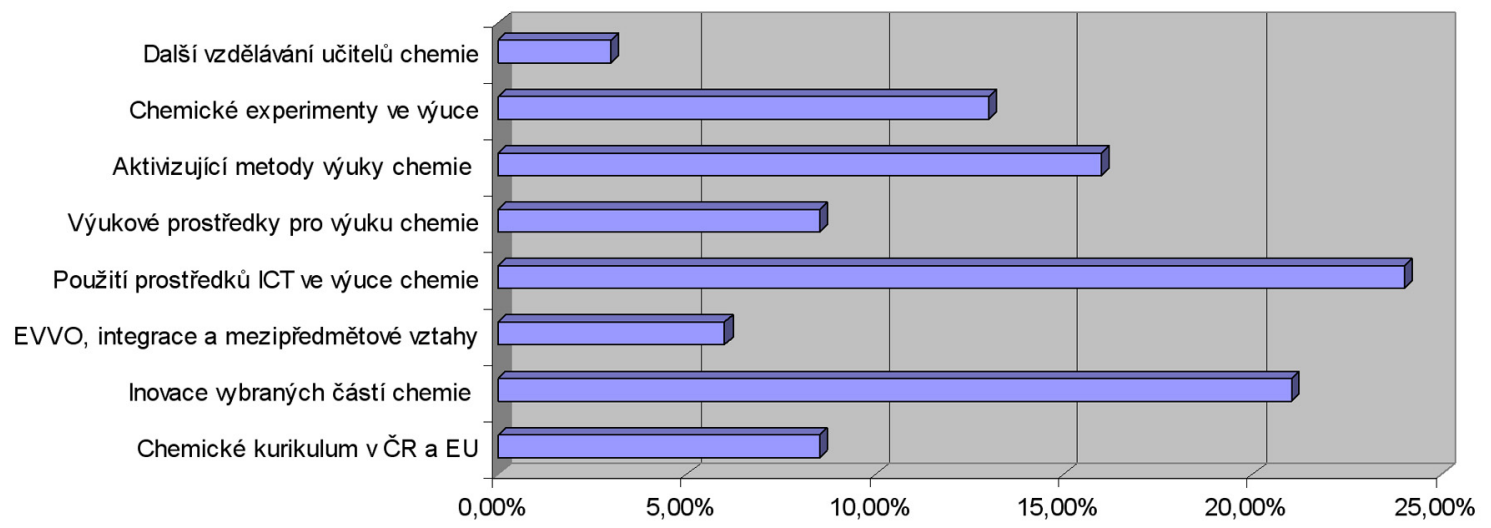

Obr. 2: Témata prací doktorského studia z didaktiky chemie (2004-2010)

Poměrně malá část studentů $(8,5 \%)$ si volí jako téma práce komplexnější pohled na chemické kurikulum, at již na úrovni vybraných evropských zemí nebo na úrovni České republiky.

Větší pozornost ( $21 \%$ ) je věnována obsahové a metodické inovaci vybraných částí chemie - nejčastěji jsou voleny analytická chemie, anorganická chemie a biochemie. 
Patří sem i tvorba výukových materiálů $\mathrm{k}$ těmto částem chemie, návrh chemických experimentů, využití ICT apod. Zatím pouze $6 \%$ prací se zaměřuje na problematiku environmentální výchovy, vzdělání a osvěty (EVVO), integrace přírodovědných předmětů a mezipředmětové vztahy.

Bezkonkurenčně nejvíce prací (24 \%) je věnováno využití informačních a komunikačních technologií (ICT) při tvorbě výukových materiálů pro žáky a učitele. Jde o multimediální podpory výuky chemie, digitalizované experimenty, PowerPointové prezentace a další materiály. Klasické výukové prostředky si jako téma práce zvolilo $8,5 \%$ studentů. Jde zejména o tvorbu učebnic, modelování v chemii, vývoj nových učebních pomůcek apod.

Aktivizujícími metodami výuky chemie z hlediska pedagogicko-psychologického i oborově didaktického se věnuje $16 \%$ prací, a jen o něco méně prací $(13 \%)$ se zaměřuje na různé aspekty nejvýznamnějšího prostředku pro výuku chemie - chemického experimentu. Zatím $3 \%$ prací si zvolila jako téma další vzdělávání učitelů chemie.

Lze tedy konstatovat, že ve srovnání s předchozím obdobím se výrazně zvýšil počet prací zaměřených na využití informačních a komunikačních technologií v chemickém vzdělávání, což je bezesporu změna, kterou bylo možno očekávat. Další změnou je posun od tradičního pedagogického výzkumu a řešení obecnějších otázek (např. úrovně osvojování učiva chemie nebo rozvoje různých poznávacích činností ve výuce chemie) k otázkám akčního pedagogického výzkumu, který řeší a hodnotí nejrůznější navrhované a připravované změny v chemickém vzdělávání.

Stejně jako v minulém období je již nyní zřejmé, že připravované, či již obhájené práce zásadním způsobem přispívají k řešení aktuálních otázek oboru „chemické vzdělávání" a postupně i k dalšímu personálního zabezpečení tohoto oboru. Doktorské studium tak v souladu s našimi předpoklady významně přispívá k jeho stabilitě a k jeho dalšímu perspektivnímu vývoji.

\section{LITERATURA}

BANÝR, J. Odborná skupina pro výuku chemie ČSCH a vývoj koncepce a obsahu výuky chemie v ČR. In Aktuální otázky výuky chemie XII. Hradec Králové : Gaudeamus, 2002, s. 68-71.

BÍLEK, M. Didaktika chemie - výzkum a vysokoškolská výuka. Hradec Králové : Miloš Vognar - M \& V, 2003.

BROCKMEYEROVÁ-FENCLOVÁ, J.; ČAPEK, V.; KOTÁSEK, J.: Oborové didaktiky jako samostatné vědecké disciplíny. Pedagogika, XLX, 2000, s. 23-37.

ČTRNÁCTOVÁ, H. Chemické vzdělávání - moderní vědecká disciplína. In Acta Facultatis Paedagogicae Universitatis Tyrnaviensis, Séria D - Vedy o výchove a vzdelávaní, Supplementum 1 - Aktuálne vývojové trendy vo vyučování prírodných vied. Trnava, Trnavská univerzita, 9, 2006 (2005), s. 157-160.

HELLBERG, J.; BÍLEK, M. Vývoj chemického vzdělávání v souvislosti s rozvojem chemie jako vědy. Chemické listy, 94, č. 12, 2000, s. 1125-1131.

McMILLAN, J. H.; WERGIN, J. F. Understanding 8 Evaluating Educational Research. New Jersey : Prentice-Hall, Inc., 1998.

PFEIFER, P.; HÄUSLER, K.; LUTZ, B. a kol. Konkrete Fachdidaktik Chemie. Neueerarbeitung. München : Oldenbourg Verlag GmbH, 2002. 
SCHMIDT, H. J. a kol. Empirical Research in Chemistry and Physics Education. Proceedings of the International Seminar ICASE. Dortmund : University of Dortmund, 1992.

Studium - Agenda doktorského studia [online]. Praha : Přírodovědecká fakulta UK, 2010 [cit. 2010-11-12]. Dostupné z: 〈http://www.natur.cuni.cz〉

Studium - Doktorské studium [online]. Olomouc : Přŕrodovědecká fakulta UP, 2010 [cit. 2010-11-14]. Dostupné z: 〈http://www.upol.cz〉

prof. RNDr. Hana Čtrnáctová, CSc. - E-mail: ctr@natur.cuni.cz

Univerzita Karlova v Praze, Př́rodovědecká fakulta, katedra učitelství a didaktiky chemie Albertov 6, 12843 Praha 2, Česká republika

doc. RNDr. Marta Klečková, CSc. - E-mail: kleckova@prfnw.upol.cz

Univerzita Palackého v Olomouci, Př́rodovědecká fakulta, katedra anorganické chemie

17. listopadu 12, 77146 Olomouc, Česká republika 